\title{
ANALISIS FUNDAMENTAL DAN TEKNIKAL SAHAM PT. BANK BTPN SYARIAH TbK
}

\author{
Meidya Putri' ${ }^{1}$, Husni Shabri ${ }^{2}$ \\ Corresponding Author's : Institut Agama Islam Negeri Batusangkar \\ Email: putrimeidya93@gmail.com \\ Copyright (C) 2022 \\ 13002
}

\begin{abstract}
The purpose of this study is to determine whether the company's fundamental performance is in line with stock price movements in the Capital Market. The research was conducted using a qualitative descriptive method. The analysis technique is fundamental analysis and technical analysis of PT. Bank BTPN Syariah Tbk. The data used are financial reports and stock trading statistics obtained from the Indonesia Stock Exchange. The results showed that the fundamental performance since 2015-2019 as measured by EPS, ROE, ROE and PER showed very good growth. Meanwhile, along with the ongoing pandemic in 2020, there was a decline in fundamental performance with indicators of EPS, ROE, ROA dropping significantly. Meanwhile, in terms of technical analysis, it is in line with the company's performance. Where from 2018 to 2019 the stock price experienced an uptrend (increase) phase and PER was at 14-15x, which means the stock price was considered cheap (undervalued). Meanwhile in 2020, along with the decline in fundamental performance, the movement of BTPS stock prices experienced a downtrend phase with stock valuations being quite expensive (overvalued) at $43 \mathrm{x}$.
\end{abstract}

Keywords: Fundamental analysis, technical analysis, BTPN Syariah Stock

\begin{abstract}
Abstrak : Tujuan penelitian ini untuk mengetahui kinerja fundamental perusahaan yang sejalan dengan pergerakan harga saham di Pasar Modal. Penelitian ini menggunakan metode deskriptif kualitatif. Teknik analisis yang digunakan adalah analisis fundamental dan analisis teknikal PT. Bank BTPN Syariah Tbk. Data yang digunakan adalah laporan keuangan dan statistik perdagangan saham yang diperoleh dari Bursa Efek Indonesia. Hasil penelitian menunjukkan bahwa kinerja fundamental sejak 2015-2019 yang diukur dengan EPS, ROE, ROE dan PER menunjukkan pertumbuhan yang sangat baik. Sedangkan pada berlangsungnya pandemi di tahun 2020, terjadi penurunan kinerja fundamental dengan indikator EPS, ROE, ROA turun signifikan. Sedangkan dari sisi analisis teknikal sejalan dengan kinerja perusahaan. Tahun 2018 sampai 2019 harga saham mengalami fase uptrend (kenaikan) dan PER berada pada level 14-15x, artinya harga saham tersebut dinilai murah (undervalued). Sementara pada tahun 2020 seiring dengan penurunan kinerja fundamental, pergerakan harga saham BTPS mengalami fase downtrend dengan valuasi saham yang overvalued sebesar 43x.
\end{abstract}

Kata Kunci: Analisis Fundamental, Analisis Teknikal, Saham BTPN Syariah 


\section{PENDAHULUAN}

Perkembangan aktivitias ekonomi dan keuangan syariah di Indonesia terus mengalami kemajuan. Banyaknya Lembaga Keuangan syariah yang terus bersinergi menjalankan aktivitas keuangan berdasarkan prinsip syariah memberikan dampak positif bagi masyarakat Indonesia. Lembaga keuangan syariah yang dimaksud seperti perbankan syariah, Pasar modal syariah maupun Industri Keuangan NonBank (IKNB) Syariah. Adanya dukungan literasi dan inklusi keuangan syariah juga menjadi pemicu terhadap kemajuan dan eksistensi Lembaga keuangan berbasis syariah tersebut dalam kehidupan masyarakat Indonesia.

Berdasarkan Laporan Perkemba ngan Keuangan Syariah tahun 2020, Industri Perbankan Syariah saat ini mencapai 197 Institusi yang meliputi 14 Bank Umum Syariah (BUS). Adanya Marger BNI syariah dengan BRI Syariah dan Bank Syariah Mandiri pada awal tahun 2021 mengakibatkan jumlah bank umum syariah secara korporasi menjadi 12 Bank Umum Syariah. Selebihnya adalah 20 Unit Usaha Syariah (UUS) dan 163 Bank Perkreditan Rakyat Syariah (BPRS) yang tersebar di Indonesia. Berdasarkan perkembangan market share perbankan syariah, terjadi kenaikan menjadi $6,41 \%$ dengan penyebaran market share terbanyak yakni pada sektor Bank Umum Syariah sebanyak 65,21\%, diikuti oleh Unit
Usaha Syariah 32,33\% dan BPRS dengan market share 2,45\%.

Tidak hanya dari sisi market share, bahkan dari jumlah asset perbankan syariah dilaporkan oleh Otoritas Jasa Keuangan bahwa terdapat pertumbuhan asset dari 2017 ke 2021. Yakni dari 435,02 tirliun Rupiah menjadi 608,90 triliun Rupiah. Tentunya dengan penyebaran asset terbesar ada pada Bank Umum Syariah.

Berdasarkan data di atas, dapat dikatakan bahwa optimisme akan kemajuan perbankan syariah di Indonesia semakin tinggi. Kendati menurut hasil analisis Rusydiana (2016) banyak tantangan yang harus dihadapi perbankan syariah. Salah satunya bank syariah harus terus memperkuat permodalan dan skala usaha serta terus memperbaiki tingkat efisiensi, memiliki struktur dana yang mendukung untuk peningkatan kinerja yang semakin cemerlang di masa depan.

Sehubungan dengan tantangan permodalan tersebut, Pasar Modal menjadi salah satu alternatif Lembaga perbankan syariah untuk memperoleh modal tambahan. Hal ini terbukti nyata menjadi solusi bagi beberapa perusahaan perbankan syariah yang memutuskan untuk go public dan melakukan Initial Public Offering (IPO). Adapun Initial Public Offering (IPO) merupakan suatu kegiatan yang dilakukan oleh perusahaan dalam bentuk penawaran perdana saham perusahaan kepada publik sesuai 
dengan ketentuan dan peraturan yang berlaku (Widoatmodjo, 2015).

Tujuan utama dari kegiatan

Penawaran perdana oleh perusahaan tentu untuk memperoleh suntikan dana dari masyarakat investor yang nantinya akan digunakan untuk meningkatkan kinerja perusahaan. Lebih lanjut Widoatmodjo (2015) menerangkan bahwa Kegiatan go public dalam pengertian lain dipahami sebagai istilah yang menunjukkan adanya penghimpunan dana dari masyarakat. Jadi, jika perusahaan ingin mendapatkan modal tambahan maka salah satu caranya dengan menjual sebagian saham perusahaan ke masyarakat. Adapun daftar bank umum syariah yang sudah tercatat di Bursa Efek Indonesia dan melakukan IPO terlihat pada Tabel. 1 berikut:

Tabel. 1

Daftar Perbankan Syariah yang sudah go public

\begin{tabular}{cll}
\hline No & \multicolumn{1}{c}{ Nama Perusahaan } & \multicolumn{1}{c}{ Tahun IPO } \\
\hline $\mathbf{1}$ & PT. Bank Panin Dubai Syariah Tbk & 15 Januari 2014 \\
\hline $\mathbf{2}$ & PT. Bank BTPN Syariah & 08 Mei 2018 \\
\hline $\mathbf{3}$ & $\begin{array}{l}\text { PT. Bank Syariah Indonesia Tbk (Saat IPO oleh PT. } \\
\text { BRI Syariah Tbk) }\end{array}$ & 09 Mei 2018 \\
\hline $\mathbf{4}$ & PT. Bank Aladin Syariah & 01 Februari 2021 \\
\hline & \multicolumn{1}{c}{ Sumber: $\underline{w} w$ w.idx..co.id }
\end{tabular}

Berdasarkan Tabel. 1 di atas dapat dilihat bahwa hingga tahun 2017, hanya satu perusahaan perbankan syariah yang sudah go public dan mendapatkan dana modal tambahan dari masyarakat. Sementara pada tahun 2018 terdapat dua bank umum syariah yang juga memutuskan untuk go public dan mendapatkan tambahan modal dari masyarakat. Bahkan adanya pandemi covid sejak tahun 2019 akhir hingga sekarang, tidak menyurutkan langkah perusahaan perbankan syariah yakni PT. Bank Aladin Syariah untuk mencatatkan sahamnya di Bursa Efek Indonesia melalui IPO.

Tabel. 2 berikut merupakan data perolehan dana IPO oleh masingmasing perusahaan perbankan syariah yang IPO selama 4 tahun terakhir:

Tabel. 2

Jumlah Dana Perolehan IPO oleh Perusahaan

\begin{tabular}{rlr}
\hline No & \multicolumn{1}{c}{ Nama Perusahaan } & $\begin{array}{r}\text { Perolehan Dana IPO } \\
\text { (Rp dalam Juta) }\end{array}$ \\
\hline $\mathbf{1}$ & PT. Bank BTPN Syariah (BTPS) & 751.111 \\
\hline $\mathbf{2}$ & PT. Bank BRI Syariah (BRIS) & 1.337 .909 \\
\hline $\mathbf{3}$ & PT. Bank Aladin Syariah (BANK) & 515.000 \\
\hline & Sumber: $w$ ww.idx.co.id
\end{tabular}

14 | Analisis Fundamental dan Teknikal Saham PT. Bank BTPN Syariah Tbk 
Berdasarkan informasi dari Tabel. 2 di atas, terlihat bahwa PT. Bank BRI Syariah tahun 2018 memiliki tambahan modal dari proses IPO paling banyak diantara perbankan lainnya yakni lebih dari 1, 3 triliun, dan diikuti oleh PT. Bank BTPS Syariah dan Bank Aladin Syariah Tbk.

Sehubungan dengan PT Bank BTPN Syariah Tbk merupakan bank yang memfokuskan diri untuk melayani segmen market yang terdiri dari para pensiunan, pelaku usaha mikro, kecil, dan menengah (UMKM), segmen consuming class; serta segmen korporasi didukung unit-unit bisnis Bank BTPN, yaitu BTPN Sinaya - unit bisnis pendanaan, BTPN Purna Bakti unit bisnis yang fokus melayani nasabah pensiunan, BTPN Mitra Usaha Rakyat - unit bisnis yang fokus melayani pelaku usaha mikro, BTPN Mitra Bisnis - unit bisnis yang fokus melayani pelaku usaha kecil dan menengah, BTPN Wow! - produk Laku Pandai yang fokus pada segmen unbanked, Jenius - platform perbankan digital untuk segmen consuming class, serta unit bisnis korporasi yang fokus melayani perusahaan besar nasional, multinasional dan Jepang.

Permasalahan dalam penelitian ini adalah adanya fenomena pergerakan harga saham yang cenderung saat IPO mengalami grafik kenaikan dari harga saat Penawaran Perdana atau IPO. Antusias pelaku pasar dalam men transaksikan saham emiten khususnya PT. Bank BTPN Syariah dengan kode BTPS ditawarkan Rp 975 per saham, dan kemudian setelah diperdagangkan di pasar modal dan kurang dari 2 tahun harga saham sudah mencapai Rp 4.480 per saham. Level harga tersebut terjadi pada 03 Februari 2020. Akan tetapi, Gejolak pandemic covid 19 mengakibat kan dampak serius di seluruh sektor termasuk pasar modal. Tidak terkecuali saham BTPS yang mengalami penurunan terus menerus hingga ke harga Rp 2540 per 23 Juli 2021.

Berdasarkan informasi dari Statistik pasar modal di atas dapat disimpulkan bahwa setahun terakhir saham BTPS sudah mengalami penurunan sebesar 30,87\%. Selain itu, menurut Fahmi (2013) pergerakan harga saham juga dipengaruhi oleh banyak faktor termasuk kinerja fundamental perusahaan. Maka dari itu, penulis juga tertarik untuk meng analisis kinerja saham perusahaan dipasar modal dengan kinerja keuangan yang dicapai oleh perusahaan. Pernyata an tersebut juga didukung oleh peneliti an Pradhan \& Paudel (2017) pada Bank Komersial Nepal bahwa variabel fundamental perusahaan berpengaruh positif terhadap pergerakan harga saham. Sementara pada beberapa hasil penelitian di Indonesia, diantaranya Abdulmannan \& Faturohman (2015) menyimpulkan bahwa secara statistik tidak ada hubungan signifikan antara variabel fundamental perusahaan dengan harga saham perbankan di Indonesia yang terdaftar di Bursa Efek Indonesia. Selain itu, pengujian faktor fundamental terhadap harga saham juga dilakukan oleh Melani (2017) 
dengan kesimpulan bahwa variabel fundamental tidak berpengaruh ter hadap harga saham perusahaan yang terdaftar di Bursa Efek Indonesia.

Adapun pertanyaan penelitian yakni bagaimana kondisi fundamental PT. BTPN Syariah Tbk. dan pergerakan harga sahamnya di pasar modal sejak IPO hingga pandemi covid 19. Per masalahan ini penting untuk diteliti agar dapat menjadi pertimbangan dalam pengambilan keputusan investasi.

\section{KAJIAN TEORI}

\section{Perbankan Syariah di Indonesia}

Berdasarkan Undang-Undang nomor 21 Tahun 2008, yang dimaksud perbankan syariah adalah segala sesuatu yang mengyangkut tentang bank syariah dan unit usaha syariah baik secara kelembagaan, kegiatan usaha serta cara dan proses dalam melaksanakan kegiatan usahanya. Sementara bank syariah diartikan sebagai bank yang menjalankan kegiatan usahanya berdasarkan prinsip syariah dan menurut jenisnya terdiri dari Bank Umum Syariah dan Bank Pembiayaan Rakyat Syariah.

Pasal 1 ayat 12 pada UndangUndang tersebut juga mendefinisikan prinsip syariah dengan konsep prinsip hukum Islam dalam kegiatan perbankan berdasarkan fatwa yang dikeluarkan oleh Lembaga yang memiliki kewenangan dalam penetapan fatwa di bidang syariah. Sektor Perbankan syariah sebagaimana dimaksud dalam Undang-Undang di 16 | Analisis Fundamental dan Teknikal Saham PT. Bank BTPN Syariah Tbk atas meliputi Bank Umum syariah dan Bank Pembiayaan Rakyat syariah. Secara umum terdapat perbedaan pokok antara keduanya. Bank Syariah dengan jenis BPRS dilarang menerima simpanan berupa giro dan ikut serta dalam lalu lintas sistem pembayaran layaknya Bank Umum Syariah.

Secara kelembagaan bank umum syariah dapat berbentuk bank syariah penuh (full-pledged) dan/atau bentuk Unit Usaha Syariah (UUS) dari bank umum konvensional. Undang-Undang Perbankan Syariah juga mewajibkan setiap pihak yang melakukan kegiatan penghimpunan dana masyarakat dalam bentuk simpanan atau investasi berdasarkan prinsip syariah harus terlebih dahulu mendapat izin 0JK.

Lestari (2015) memetakan fungsi Perbankan Syariah diantaranya pertama, penghimpunan dana dan menyalurkannya kepada masyarakat, kedua fungsi sosial dalam bentuk Lembaga Baitul maal, menghimpun dana yang berasal dari zakat, infaq, sedekah dan dana social lainnya serta menyalurkannya kepada Lembaga pengelola zakat, infaq dan sedekah.

Adapun pada fungsi pertama, kegiatan Bank Syariah secara umum dapat diuraikan sebagai berikut :

1) Menghimpun dana dalam bentuk simpanan, giro, atau bentuk lainnya yang dipersamakan dengan itu berdasarkan akad yang sesuai

2) Menghimpun dana dalam bentuk investasi berdasarkan akad yang sesuai 
3) Menyalurkan pembiayaan berdasar kan akad sesuai prinsip syariah

Selain dari kegiatan pokok di atas, Bank syariah juga dapat melakukan kegiatan jual beli, penitipan dan penyimpanan surat berharga, wali amanat, serta kegiatan lazim lainnya di bidang perbankan dan sosial yang tidak bertentangan dengan prinsip syariah serta sesuai dengan perundangundangan yang berlaku.

Adanya informasi perkembangan dan pertumbuhan bank syariah di Indonesia menunjukkan bahwa eksistensi perbankan syariah sangat berarti dan penting bagi pembangunan ekonomi berwawasan syariah. Terutama dalam memberikan solusi bagi pemberdayaan usaha mikro, dan menengah (Rusydiana, 2016).

Kemajuan bank syariah dan perannya dalam membantu masyarakat melalui pembiayaan sangat ditentukan oleh kapasitas modal dan dana yang ada di perbankan. Salah satu cara meningkatkan pendanaan/modal bagi perbankan adalah dengan menjual sebagian saham kepada masyarakat melalui proses go public (Harmono, 2014).

\section{Go Public dan Initial Publik Offering (IPO)}

Adanya pasar modal di Indonesia menjadi alternatif saranan bagi perusahaan memperoleh sumber pendanaan. Kegiatan yang dilakukan oleh perusahaan untuk hal tersebut diistilahkan dengan go public. Istilah ini menurut Widioatmodjo (2015) sebenarnya memiliki arti bahwa perusahaan menjual saham biasa atau saham preferen, atau obligasi yang merupakan modal perusahaan untuk pertama kalinya kepada masyarakat luas. Istilah go public juga sering disebut IPO (initial Public Offering).

Kedua istilah tersebut seringkali dimaknai sama, namun pada realitasnya proses IPO hanya dapat dilakukan sekali saja, sementara go public bisa dilakukan oleh perusahaan berkali-kali. Perusahaan yang telah go public disebut dengan perusahaan publik dengan kategori ada perusahaan publik yang tercatat dan ada yang tidak tercatat. Adapun tercata, artinya saham tersebut tercatat di Bursa Efek dan ditransaksikan, sementara saham yang tidak tercatat artinya saham perusahaan dijual keapda masyarakat tanpa dicatatkan pada bursa efek (Widioatmodjo, 2015).

Berdasarkan pusat informasi Bursa Efek Indonesia, proses go public dibagi menjadi beberapa tahap. Pertama, perusahaan perlu menyiapkan tim internal, menunjuk Penjamin Emisi Efek serta Lembaga dan profesi penunjang pasar modal yang akan membantu perusahaan melakukan persiapan go public, meminta per setujuan RUPS serta mengubah Anggaran dasar serta mempersiapkan dokumen-dokumen yang diperlukan untuk disampaikan kepada Bursa Efek Indonesia dan Otoritas jasa Keuangan.

Tahap kedua, perusahaan perlu menyampaikan permohonan pencatat an saham ke Bursa Efek Indonesia dan Penyampaian Pernyataan Pendaftaran 
Efektif ke Otoritas Jasa Keuangan. Ketiga, Prose Penawaran Umum saham kepada publik yang dibantu oleh Penjamin Emisi dan terakhir keempat, pencatatan dan perdagangan saham perusahaan di Bursa Efek Indonesia.

\section{Analisa Fundamental Perusahaan}

Keberhasilan setiap perusahaan dalam menjalankan kegiatan usahanya adalah dengan terwujudnya kinerja yang sesuai dengan target atau lebih baik dari waktu ke waktu. Untuk mengetahui kinerja perusahaan dapat dilakukan dengan menganalisis laporan keuangan perusahaan. Sejalan dengan itu, perusahaan dapat mengetahui tolak ukur kinerja keuangan dengan membandingkan kinerja perusahaan dengan perusahaan lain pada industri yang sama. Tidak hanya itu, perusahaan juga dapat melakukan evaluasi terhadap capaian kinerja dari periodeperiode sebelumnya (Brigham dan Ehrhardt, 2010).

Kinerja Perusahaan menurut Harmono (2014) umumnya diukur berdasarkan penghasilan bersih atau imbalan investasi (Return on investment) atau penghasilan per saham (Earnings per share). Dimana kedua rasio tersebut adalah indikator untuk mengukur profitabilitas perusahaan yang dapat mewakili kinerja fundamental dan manajemen perusahaan. Sementara menurut Tendelilin (2010) menyebutkan bahwa dua unsur penting dalam analisis fundamental yaitu: Earning per Share (EPS) dan Price Earnings Ratio (PER).
Kedua pendapat ini dapatdipahami bahwa selain unsur profitabilitas juga terdapat rasio pasar yang bisa digunakan untuk menganalisa kondisi fundamental perusahaan.

Apabila kinerja kinerja manajemen perusahaan yang diukur dengan dimensi profitabilitas dalam kondisi baik, maka akan memberikan dampak pada keputusan investor di pasar modal untuk berinvestasi pada perusahaan. Dengan demikian, minat investor akan semakin meningkat untuk membeli saham perusahaan di pasar modal jika kinerja perusahaan semakin baik. Alhasil, kekuatan penawaran beli dari masyarakat dan investor akan meningkat dan tentunya berdampak pada naiknya harga saham tersebut (Christina, dkk, 2021).

Analisis fundamental sangat penting bagi perusahaan maupun pihak investor. Informasi keuangan perusahaan menjadi salah satu cara untuk mengetahui kondisi fundamental perusahaan. Menurut tendelilin (2010), penggunaan unsur fundamental sangat penting karena dapat mengetahui informasi tentang nilai instrinsik perusahaan. Selain itu, dengan mengetahui nilai instrinsik perusahaan, dapat juga dibandingkan dengan nilai pasar saham untuk menentukan keputusan beli atau menjual bagi investor.

\section{Earnings per Share (EPS)}

laba per saham atau disebut Earning per Share (EPS) akan menunjukkan informasi tentang besarnya laba bersih

18 | Analisis Fundamental dan Teknikal Saham PT. Bank BTPN Syariah Tbk 
perusahaan yang akan dibagikan kepada pemegang saham perusahaan. Berikut adalah rumus untuk menghitung EPS :

EPS $=\frac{\text { laba bersih setelah bunga dan pajak }}{\text { jumlah saham beredar }}$

\section{Price Earnings Ratio (PER)}

Rasio ini akan menunjukkan informasi tentang besarnya rupiah yang harus dibayarkan investor untuk memperoleh satu raupiah laba perusahaan. Rasio PER diperoleh dari perhitungan harga saham terhadap laba perusahan (Harahap, 2015). Adapun rumus untuk menghitung nilai PER adalah :

$P E R=\frac{\text { Price per Share }}{\text { Earnings per share }}$

Kinerja fundamental perusahaan juga dapat dilihat dari rasio profitabilitas. Profitabilitas menggambarkan kemampuan perusahaan mendapatkan laba melalui kemampuan dan sumber daya yang ada. Rasio profitabilitas mengukur efektifitas manajemen berdasarkan hasil pengembalian yang diperoleh dari penjualan dan investasi (Harahap, 2015). Menurut Brigham dan Ehrhardt profitabilitas merupakan hasil dari sejumlah kebijakan atau keputusan terhadap efektifitas operasional.

Lebih lanjut, indikator profitabilitas mempunyai arti penting dalam usaha mempertahankan kelangsungan hidup perusahaan untuk jangka panjang. Tingkat profitabilitas menunjukkan bagaimana prospek di masa yang akan datang. Indikator rasio profitabilitas diantaranya sebagai berikut (Brigham dan Ehrhardt, 2010):

\section{Return on Equity}

Return on Equity (ROE) menurut Djaja (2010) dapat dihitung dengan:

$$
\mathrm{ROE}=\frac{\text { Laba Bersih }}{\text { modal }}
$$

Rasio ini akan menunjukkan berapa persen diperoleh laba bersih bila diukur dari modal pemilik. Jika rasio ROE semakin tinggi maka menunjukkan kinerja perusahaan semakin baik. Dengan kata lain, ROE akan mencerminkan kemampuan perusahaan dalam menggunakan modalnya (Harahap, 2015).

\section{Return on Asset}

Rasio ini memiliki perhitungan matematis sebagai berikut Harahap (2015):

$$
\mathrm{ROA}=\frac{\text { Laba Bersih }}{\text { rata }- \text { rata total Aset }}
$$

Adapun net income yang digunakan dalam rumus ROA adalah net income setelah dikurangi bunga dan pajak. Adapun istilah lainnya adalah return on total assets (Brigham dan Ehrhardt, 2010). Rasio ini akan menunjukkan tingkat perputaran aset yang diukur dari volume penjualan. Semakin tinggi angka rasio perputaran aset maka bermakna bahwa efisiensi penggunaan aset untuk meraih laba semakin tinggi (Harahap, 2015).

\section{Analisa Teknikal}

Pengukuran kinerja yang mencerminkan nilai perusahaan publik tidak hanya dari sisi keuangan, namun 
juga dari sudut pandang saham di pasar modal. Hal ini dikarenakan saham perusahaan yang tercatat di Bursa Efek Indonesia akan ditransaksikan oleh masyarakat luas. Dengan demikian pergerakan harga saham perusahaan cenderung mengalami fluktuasi karena berbagai faktor yang mempengaruhinya. Kendati pergerakan harga saham diyakini akan mencerminkan nilai perusahaan, namun seringkali juga berlawanan arah dengan kinerja fundamental perusahaan (Yoga, Zahidah dan Muharrami dkk, 2017).

$$
\text { Menurut Fahmi }
$$

pergerakan harga saham di pasar modal dipengaruhi oleh faktor eksternal dan internal. Faktor eksternal diantaranya seperti keadaan ekonomi nasional dan global, suku bunga perbankan, pertumbuhan laju ekonomi dan sebagainya. Selain analisis fundamental, penilaian kinerja saham dapat dilakukan dengan analisis teknikal. Analisis teknikal adalah Teknik analisis yang dapat dilakukan untuk memprediksi arah pergerakan saham dan indikator pasar saham lainnya dengan memanfaatkan data historis masa lalu (Harwaningrum, 2016).

\section{Teori Analisis Teknikal}

Analisis teknikal yang umumnya dilakukan oleh pelaku pasar dapat mengacu kepada beberapa teori; The Dow Theory, analisis rata-rata bergerak (moving average), chart pola harga saham dan/atau menggunakan indikator teknikal lainnya (Filbert, R, 2016).

Teori pertama yang digunakan adalah The Dow Theory. Teori ini diperkenalkan oleh Charles $H$. Dow pada tahun 1897. Charles H. Dow merupakan salah satu editor dari Wall Street Journal. Teknik ini merupakan Teknik yang sering menjadi acuan bagi pelaku pasar untuk menilai kinerja saham di pasar modal (Tendelilin, 2010). Adapun asumsi dasar dalam teori ini diantaranya :

1) Market Price discount Everything

Pergerakan harga saham sudah merefleksikan semua informasi yang ada, informasi yang dimiliki oleh para pelaku pasar. Dalam asumsi ini, dapat dipahami bahwa pergerakan harga saham merupakan cerminan dari informasi yang dimiliki. Informasi yang dimaksud seperti laporan kinerja perusahaan, isu dan rumor, ataupun informasi eksternal lainnya.

2) Market Has Three Movements

Meurut teori Dow, pergerakan harga saham terbagi atas tiga trend yaitu primary trend, secondary trend dan minor trend. Dimana primary trend adalah pergerakan saham dalam kurun waktu Panjang. Umumnya untuk waktu kurang lebih 9 bulan ke atas. Sementara secondary trend adalah pergerakan saham yang terjadidalam kurun waktu 3 minggu - 9 bulan, sedangkan minor trend adalah istilah untuk pergerakan harga saham dalam rentang waktu 
jangka pendek. Umumnya

pergerakan dianalisis dalam hitungan menit, jam atau hari.

3) Trend are Confirmed by Volume

Pada asumsi ini, pergerakan harga saham akan diikuti oleh pergerakan volume transaksi. Hal ini dapat dipahami bahwa kenaikan/ penurunan volume transaksi dapat mempengaruhi tren harga saham.

4) Trends Exist Until Definitive Signals Prove That They Have Ended

Kalimat di atas secara umum dapat dipahami bahwa sebuah trend/kecenderungan akan terus bergerak (naik/turun/mendatar) hingga sebuah sinyal menandakan pergerakan trend tersebut berubah.

Teori kedua, indikator moving average atau rata-rata bergerak. Menurut Harwaningrum (2016) Teknik ini dapat digunakan untuk mendapatkan informasi mengenai arah pergerakan harga saham dan besarnya tingkat pergerakan harga saham tersebut. Analisis teknikal dengan indikator ini memanfaatkan data harga penutupan yakni fengan menghitung nilai rata-rata bergerak dari harga penutupan saham haria nselama beberapa periode pengamatan (tendelilin, 2010).

Ketiga, indikator Relative strength merupakan Teknik Analisa dnegan pendekatan rasio, yaitu harga saham dengan indeks pasar atau industry tertentu. Secara sederhana, analisis ini membandingkan kinerja suatu saham dengan kinerja kelompok industrinya. Jika menggunakan Teknik ini, investor dapat mengetahui trend pergerakan harga saham. Asumsi dari penggunaan Teknik ini yaitu apabila trend menunjukkan pergerakan saham yang meningkat maka itu pertanda / signal bahwa peningaktan rasio harga saham akan meningkat.

Beberapa teori teknikal juga telah diuji dan digunakan oleh para peneliti baik di Indonesia maupun negara lain, seperti yang dilakukan Vinccent (2018) dengan judul A Study of Technical Analysis of Select Banking Stock dengan kesimpulan bahwa teknikal analisis lebih dapat diandalkan untuk membantu investor mengambil keputusan yang tepat kapan sebaiknya membeli dan menjual saham.

Lebih lanjut menurut Vincent (2018) jika Analisa fundamental membantu untuk mengetahui nilai instrinsik dari saham tertentu, maka analisis teknikal seperti trend dan chart akan mengkonfirmasi tren harga dan membantu pengambilan keputusan oleh investor.

Beberapa perbedaan antara Analisa fundamental dan Analisa teknikal diantaranya adalah penekanan Analisa, cara dan data yang digunakan. Pada Analisa fundamental, fokus analisis pada faktor ekonomi dan industri serta keadaan keuangan perusahaan yang dapat mempengaruhi kinerja perusahaan, sementara analisa teknikal cenderung fokus pada historis pergerakan harga saham di masa lalu yang bisa dilihat dari trend, chart dan volume perdagangannya. 
Sementara dari sisi pengguna, Analisa fundamental lebih banyak digunakan oleh investor jangka Panjang, sementara Analisa teknikal umumnya digunakan para investor jangka pandek dan menengah untuk menilai sebuah saham.

Penelitian ini merupakan rplika dari beberapa penelitian yang serupa seperti Abdul Mannan dan Fatohrahman (2015), Harwaningrum (2016), Yoga, Zahidah dan Muharrami (2017) dan Pradhan dan Paudel (2017). Sementara itu, penelitian ini juga merupakan penelitian lanjutan dari penelitian Alimul Abyadh (2020) tentang Analisis Komparatif kinerja keuangan PT. Bank BRI Syariah dan PT. bank BTPN Syariah sebelum dan sesudah IPO, Vincent (2018) yang terbatas pada analisis fundamental saja.

\section{METODE PENELITIAN}

Penelitian ini termasuk penelitian deskriptif kualitatif dengan metode penelitian menggunakan dua tahap, yakni analisis kinerja fundamental dan dilanjutkan dengan analisis teknikal. Data yang digunakan yakni data sekunder berupa dokumen laporan keuangan dan data perdagangan saham perusahaan serta publikasi lainnya yang relevan. Sumber data berasal dari website Bursa Efek Indonesia.

Pengumpulan data dilakukan dengan teknik dokumentasi yang kemudian di analisis secara deskriptif dengan tahap analisis fundamental dan diikuti dengan analisis teknikal. Adapun yang menjadi objek penelitian adalah PT. Bank BTPN Syariah. Perusahaan publik ini erupakan satu-satunya bank syariah fokus pada produk dana layanan kelaurga pra sejahteraproduktif di Indonesia dan melakukan IPO di Bursa Efek Indonesia pada bulan 09 Mei 2018 dengan saham yang dicatatkan sebanyak 7,626,663, 000 saham dengan kepemilikan public < $5 \%$.

\section{HASIL DAN PEMBAHASAN}

\section{Analisis Fundamental PT. BTPN Syariah Tbk}

PT. Bank BTPN Syariah Tbk. Selama lima tahun terakhir dapat dikatakan memiliki fundamental yang diwakili oleh indikator profitabilitas yang terus meningkat. Hal ini sebagaimana terlihat pada Tabel. 3 berikut:

Tabel. 3

Data Rasio Keuangan PT. Bank BTPN Syariah Tbk.

\begin{tabular}{ccccc}
\hline Tahun & ROA $(\%)$ & ROE $(\%)$ & EPS (Rp) & PER (x) \\
\hline 2015 & 5.24 & 17.9 & 27 & - \\
2016 & 8.98 & 31.7 & 59 & - \\
2017 & 11.19 & 36.5 & 97 & - \\
2018 & 12.4 & 30.8 & 130 & 14.7 \\
2019 & 13.6 & 31.2 & 182 & 15.68 \\
2020 & 7.16 & 16.08 & 87.7 & 43 \\
\hline \multicolumn{5}{c}{ Sumber: Ikhtisar Keuangan diolah tahun 2021 }
\end{tabular}


Berdasarkan informasi di tabel. 3, perseroan mampu meningkatkan Return on Asset (ROA) dari tahun 2015 ke tahun 2016 sebesar $3.74 \%$ dan pada tahun 2017 rasio ini tetap naik meskipun tidak lebih tinggi dari sebelumnya. Pertumbuhan ROA hanya $2.21 \%$ dengan tingkat rasio di tahun 2017 yakni 11.19\%. sementara pada tahun 2018 kenaikan ROA perseroan hanya naik sebesar $1.21 \%$. kenaikan ini dapat dikatakan semakin menurun daripada tahun 2017.

Pasca IPO di bulan MEI 2018, kinerja perseroan diharapkan semakin baik. Akan tetapi dari sisi ROA, mengalami sedikit peningkatan ke angka $12.4 \%$. sementara penggunaan dana IPO sudah mulai direalisasikan, tahun 2019 pertumbuhan ROA perseroan kembali bertumbuh sekitar $1.2 \%$ dari tahun 2018. Kondisi ini mengindikasikan bahwa profitabilitas perseroan dilihat dari tingkat ROA menunjukkan kinerja yang baik. Selain itu, dari sisi ROE, terlihat pertumbuhan yang cenderung konsisten dengan persentase kenaikan fluktuatif.

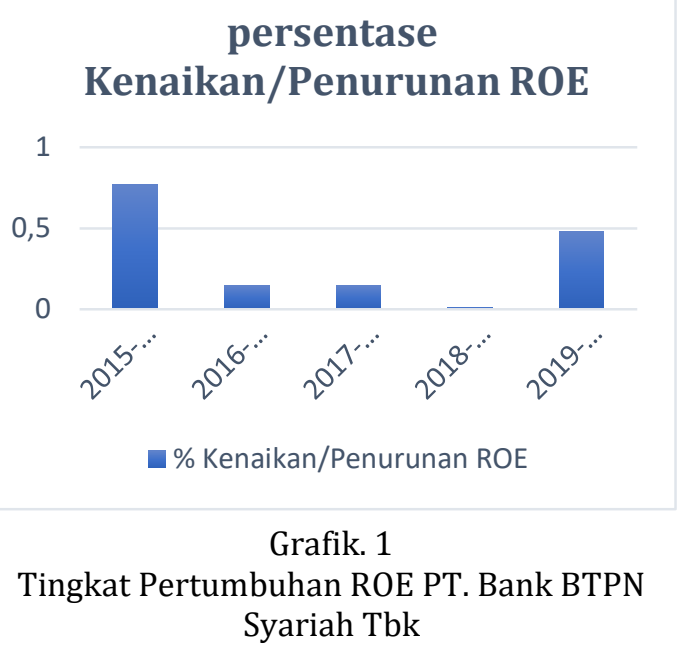

Grafik. 1 di atas menunjukkan bahwa secara keseluruhan, lima tahun terakhir rata rata pertumbuhan $\mathrm{ROE}$ cukup baik. Menurut Harahap (2015) Jika rasio ROE semakin tinggi maka menunjukkan kinerja perusahaan semakin baik. Dengan kata lain, ROE akan mencerminkan kemampuan perusahaan dalam menggunakan modal nya. Jadi dapat dikatakan bahwa PT. Bank BTPN Syariah Tbk dari tahun 2015-2017 mampu menciptakan ROE yang lebih tinggi dibandingkan tahuntahun sebelumnya. Hanya saja pada tahun 2018 terjadi penurunan ROE sebesar 0,15\% dari tahun 2017.

Penurunan ini terjadi karena pada tahun 2018, perseroan memutuskan untuk menyebar kepemilikan dengan melakukan penjualan saham melalui Initial Public Offering (IPO). Hal ini tentunya berdampak pada struktur permodalan dan kepemilihan saham perseroan. Sementara pada tahun 2019 perseroan kembali mampu mencetak kenaikan ROE ke angka 31.2\%. Artinya dengan adanya dana hasil IPO, perusahaan dapat meningkatkan kinerja pengelolaan modal yang lebih baik.

Setelah menjadi perusahaan publik dan mencatatkan sahamnya di Bursa Efek Indonesia, PT. Bank BTPN Syariah Tbk. Berhasil meningkatkan rasio earnings per share (EPS) secara konsisten hingga mencapai Rp 182. Angka ini diperoleh tahun 2019 sekaligus merupakan EPS tertinggi sejak tahun 2015. Artinya perseroan mampu meningkatkan laba per saham 
sebagaimana hal ini sangat diharapkan oleh para pemegang saham. Tingkat EPS yang tinggi menjadi salah satu alat ukur penting bagi investor dan untuk menentukan keputusan investasi mereka (Tendelilin, 2010).Sementara dari sisi Laba Bersih perseroan terlihat pada Tabel. 4 berikut:

Tabel. 4

Data Pertumbuhan Laba Bersih PT. Bank BTPN Syariah Tbk.

\begin{tabular}{ccc}
\hline Tahun & $\begin{array}{c}\text { Laba Bersih } \\
\text { (Juta Rupiah) }\end{array}$ & $\begin{array}{c}\text { Persentase } \\
\text { kenaikan / penurunan }\end{array}$ \\
2015 & 169,206 & - \\
2016 & 412,495 & 143.78 \\
2017 & 670.182 & 62.47 \\
2018 & 965,311 & 44.04 \\
2019 & $1,399,634$ & 44.99 \\
2020 & 854,614 & -38.94 \\
\hline
\end{tabular}

Sumber: Data Keuangan diolah, 2021

Pertumbuhan laba bersih PT. alami penurunan yang cukup signifikan. Bank BTPN Syariah Tbk. Dari tahun Rasio ROA, ROE dan EPS mengalami 2015 hingga tahun 2019 konsisten naik penurunan hampir 50\% dibandingkan dengan persentase yang menurun. tahun 2019. Sementara laba bersih ikut kenaikan laba bersih tertinggi dan menurun hingga 38\% dibandingkan signifikan pada PT. Bank BTPN Syariah Tbk terjadi tahun 2016 yang mencapai 143\%. Hal ini juga dapat diartikan bahwa penggunaan dana hasil IPO tahun 2018 memberikan kontribusi terhadap peningkatan kinerja laba bersih perusahaan di tahun 2019 .

Berdasarkan Analisa di atas, hingga tahun 2019 kondisi Fundamen tal perusahaan dapat dikatakan sangat baik dengan pertumbuhan profitabilitas yang konsisten. Namun pada tahun 2020, adanya pandemik covid 19 yang melanda dunia, termasuk Indonesia mengakibatkan kondisi ekonomi makro mengalami ketidak stabilan termasuk sektor keuangan dan perbankan.

Pada Tabel. 3 dan Tabel. 4 terlihat pada tahun 2020, kinerja fundamental PT. Bank BTPN Syariah Tbk. Meng tahun 2019 yakni hanya 854.614,000, 000. Sementara dari sisi harga saham, pada tahun 2018 hingga tahun 2019 mencapai kenaikan 435,9\% ke level Rp 4,250 per saham. Namun dari tahun 2020 harga saham berbalik arah dengan penurunan $40 \%$ an hingga ke harga Rp 2,540 per 23 Juli 2021.

\section{Analisa Teknikal}

PT. Bank BTPN Syariah Tbk (BTPS)

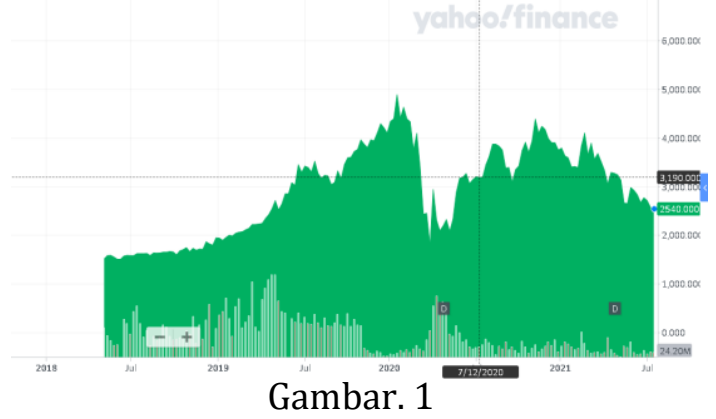

Grafik Historis Pergerakan Saham BTPS (sumber: https://finance.yahoo.com/chart/BTPS.JK) 
Berdasarkan historis harga saham PT. Bank BTPN Syariah Tbk sejak tahun 2018 hingga saat ini, dapat dikatakan bahwa harga saham saat IPO Rp975 saat ini sudah naik menjadi Rp 2,540 per 23 Juli 2021. Berdasarkan secondary trend (Tendelilin, 2020) saat ini saham BTPS berada pada fase downtrend. Secara bulanan, trend ini sudah terjadi sejak November 2020. Sementara sejak IPO hingga Juli 2021, harga saham BTPS pernah mencapai

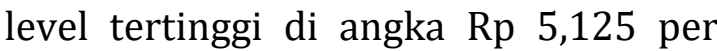
saham pada tanggal 26 Januari 2020.

Adanya fluktuasi dalam pergerakan saham BTPS, menunjukkan bahwa saham tersebut cukup banyak ditransaksikan oleh investor baik secara jangka pendek maupun menengah. Lebih rinci dijelaskan bahwa berdasarkan Gambar. 1 di atas dapat dibagi kepada (1) fase Uptrend (trend naik) dimana pasca IPO bulan Mei 2018 saham PT. Bank BTPN Syariah tbk ditransaksikan dengan peminat yang sangat tinggi mulai dari hari pertama perdagangan reguler hingga harga saham melonjak dan terus naik dari harga pembukaan Rp 1,250 tanggal 05 Juni 2018 hingga 26 Januari 2020 ditutup di harga Rp 4,410 per saham. Adapun secara volume transaksi, saham BTPS sudah ditransaksikan sebanyak 33, 18 juta saham. Fase uptrend ini mulai berbalik arah pada Februari 2020 yang disebut fase downtrend.

Pada fase downtrend saham BTPS mengalami penurunan tajam dari 02 Februari 2020 hingga 29 Maret 2020.
Penurunan harga saham BTPS mencapai $64 \%$ dari harga Rp 5,125 ke harga $\mathrm{Rp} 1,805$. Hal ini berarti terjadi penjualan saham yang lebih banyak dibandingkan pembelian. Secara sederhana dapat dipahami bahwa minat beli saham BTPS pada fase ini berkurang. Adapun salah satu penyebabnya adalah saham BTPS sudah mengalami overvalue dengan Rasio PER mencapai 43x. Jika dibandingkan dengan awal perdagangan (lihat Tabel 3) hanya $14 x$. Artinya Investor harus membayar 43 kali lipat untuk setiap laba yang dihasilkan perusahaan. Sementara untuk rasio PER, semakin tinggi nilainya menunjukkan bahwa harga saham semakin mahal (overvalue).

Selain faktor Rasio PER, penyebab lain turunnya harga saham BTPS dikarenakan secara fundamental, Laporan Keuangan Perseroan tahun 2020 dilaporkan mengalami penurunan laba bersih serta EPS yang cukup signifikan. Dengan demikian, secara tidak langsung informasi fundamental memberikan dampak terhadap pergerakan harga saham di pasar modal.

Jadi, dari Analisa fundamental dan teknikal di atas, dapat disimpulkan bahwa Potensi PT. Bank BTPN Syariah Tbk untuk terus meningkatkan kinerja fundamental masih terbuka. Hal ini dibuktikan dengan konsistensi capaian profitabilitas perusahaan ditengah pandemic covid 19. Meskipun tingkat pertumbuhan menurun, namun 
perseroan mampu survive menjalankan kegiatan usahanya.

Secara teknikal, investor jangka pendek yang cenderung menggunakan Analisa teknikal dengan trend minor disarankan untuk buy on weakness di level harga $\mathrm{Rp}$ 2,540. Sementara untuk Investor jangka Panjang yang optimis dengan kinerja perseroan ke depan dan ingin berinvestasi jangka Panjang, boleh melakukan Average Down atau membeli saham sedikit demi sedikit BTPS secara berkala.

\section{PENUTUP}

PT. Bank BTPS Syariah Tbk secara fundamental memiliki kinerja yang sangat baik. Terutama pada sisi profitabilitas yang konsisten ber tumbuh selama lima tahun terakhir. Dari sisi teknikal, saham perseroan secara umum juga mengalami kenaikan dari sejak diperdagangkan hingga saat ini. Kendati harga saham saat ini ada pada fase downtrend, namun untuk jangka Panjang prospek kinerja perseroan masih diharapkan dapat bertumbuh kembali seiring dengan pemulihan ekonomi nasional dan covid 19.

Hasil penelitian ini diharapkan dapat membantu para investor untuk menentukan pengambilan keputusan investasi jangka pendek maupun jangka Panjang. Untuk berikutnya penelitian ini dapat dikembangkan dengan model analisis yang lebih luas dan cakupan objek penelitian yang lebih banyak.

\section{DAFTAR KEPUSTAKAAN}

Abdulmannan, A, A., dan FAturohman, $\mathrm{T}, 2015$. The Relationship Between Fundamental Factors and Stock Return: A Case Based Approach on Banking Companies Listed in Indonesia Stock Exchange. Journal of Business And Management Vol. 4, No. 5, 2015 579-586

Christina, Halim, S., Angresia, V, \& Putri, A, P, 2021. Analisis Fundamental dan Teknikal terhadap harga saham pada perusahaan Utilitas dan Transportasi. E-Jurnal Akuntansi, Vol. 31, No. 2, 499-512

Fahmi, I, (2013). Pengantar Pasar Modal. Bandung: Alfabeta.

Filbert, R, 2016. Trading vs Investing. Jakarta: PT. Elek Media Komputindo

Harahap, S, S, (2015). Analisis Kritis atas Laporan Keuangan. Jakarta: Rajawali Press.

Harmono, (2014). Manajemen Keuangan. Jakarta: Bumi Aksara

Harwaningrum, M, 2016. Perbandingan penilaian Saham dengan metode analisis fundamental dan analisis teknikal, penggorengan saham dan keputusan penilaian saham. Jurnal Ilmiah Manajemen dan Bisnis Vol. 2, No. 1 Maret 2016, 138-149

Keuangan, 0, J, 2021. Laporan Pengembangan Keuangan Syariah Indonesia Tahun 2020. OJK: 2021

Lestari, N, M, 2015. Sistem Pembiayaan Bank Syariah. Jakarta: Grafindo Books Media

Melani, M, 2017. Pengaruh Faktor Fundamental terhdap harga saham pada Industri Makanan dan

26 | Analisis Fundamental dan Teknikal Saham PT. Bank BTPN Syariah Tbk 
Minuman yang Terdaftar di Bursa Efek Indonesia. Proceedings Profesionalisme akuntan menuju sustainable business practice Universitas Widyatama. 310-317

Pradhan, R, S., dan Paudel, L, 2017. Impact of Fundamental Factors on Stock Price: A Case of Nepalese Commercial Banks (September 27, 2017). Available at SSRN; https://ssrn.com/abstract=30441 08 or http://dx.doi.org/10.2139/s srn.3044108

Rusyadiana, A.S, 2016. Analisis Masalah Pengembangan Perbankan Syariah di Indonesia: Aplikasi Metode Analytic Network Process. Jurnal Bisnis dan Manajemen, Vol. 6, No. 2 Oktober 2016, 237-246

Tendelilin, E, 2010. Portofolio dan Investasi. Yogyakarta: Kanisius

Undang-Undang Nomo 21 Tahun 2008 Tentang Perbankan Syariah

Vincent, G, 2018. A Study on Technical Analysis of Select Banking Stock. International Journal of Management and Social Sciences Research (IJMSSR) Vol. 7, No. 6, June 2018, 8-12

Widoatmodjo, S, 2015. Pengetahuan Pasar Modal untuk Konteks Indonesia. Jakarta: Kompas Gramedia

Yoga, I, Zahidah, S dan Muharrami, R, S, 2017. Pergerakan Harga Saham Syariah pada Saham Bank Syariah dilihat dari Faktor Makroekonomi. Jurnal Bisnis dan Manajemen Islam Vol. 5 No. 1, Juni 2017, 175-190

www.idx.co.id

www.finance.yahoo.com 